\title{
Risk of pressure injury among users of emergency care units
}

\author{
Risco de lesão por pressão entre usuários de unidades de pronto atendimento \\ Riesgo de lesión por presión entre usuarios de unidades de emergencia
}

\author{
Danieli Parreira da Silva ${ }^{a}$ \\ Elaine Drehmer de Almeida Cruz ${ }^{\mathrm{a}}$ \\ Josemar Batista ${ }^{a}$ \\ Aline Batista Maurício ${ }^{a}$ \\ Saimon da Silva Nazário ${ }^{a}$ \\ Guilherme Parreira da Silva $^{b}$
}

\section{How to cite this article:}

Silva DP, Cruz EDA, Batista J, Maurício AB, Nazário SS, Silva GP. Risk of pressure injury among patients of emergency care units. Rev Gaúcha Enferm. 2020;41:e20190334. doi: https://doi.org/10.1590/19831447.2020.20190334
- Universidade Federal do Paraná (UFPR), Departamento de Enfermagem. Curitiba, Paraná, Brasil.

Universidade Federal do Paraná (UFPR) Departamento de Estatística. Curitiba, Paraná, Brasil.

\section{ABSTRACT}

Objective: To identify the risk of pressure injury in patients of emergency care units.

Method: Descriptive, cross-sectional, and quantitative by applying the Braden scale to 377 patients from eight units in Paraná, between April and September 2016. Descriptive statistics and Spearman's correlation were used, with a significance of $0.1 \%$ for analysis.

Results: There was a prevalence of risk-free patients (64.5\%; $n=243)$ and of older adults (54.6\%; $n=206)$; those at high risk for pressure injury were in the emergency department. Most of the variables were preserved, with emphasis on sensory perception (65.3\%; $n=246)$. The Spearman's correlation coefficient was at least 0.93 and indicated a strong linear relation between the results obtained in the variables and in the scale; it was verified that the risk for pressure injury increases with age.

Conclusions: Most of the patients were not at risk; however, the older adults and those treated in the emergency department were at high risk of developing pressure injuries.

Keywords: Emergency medical services. Pressure ulcer. Emergency nursing. Risk factors. Patient safety. Skin.

\section{RESUMO}

Objetivo: Identificar o risco de lesão por pressão em usuários de Unidades de Pronto Atendimento.

Método: Descritivo, transversal e quantitativo, mediante aplicação da escala de Braden em 377 usuários de oito unidades paranaenses, entre abril e setembro de 2016. Utilizou-se estatística descritiva e correlação de Spearman, com significância de 0,1\%, para análise.

Resultados: Houve prevalência de usuários sem risco (64,5\%; $n=243)$ e idosos (54,6\%; $n=206)$; os com risco elevado para lesão por pressão encontravam-se no setor de emergência. A maioria das variáveis esteve preservada, com destaque à percepção sensorial (65,3\%; n=246). 0 coeficiente de correlação de Spearman foi de, no mínimo,0,93 e indicou forte relação linear entre os resultados obtidos nas variáveis e na escala; constatou-se que o risco para lesão por pressão aumenta com a idade.

Conclusões: A maioria dos usuários não apresentou risco; entretanto, idosos e aqueles atendidos no setor de emergência apresentaram risco elevado para desenvolver lesão por pressão.

Palavras-chave: Serviços médicos de emergência. Lesão por pressão. Enfermagem em emergência. Fatores de risco. Segurança do paciente. Pele.

\section{RESUMEN}

Objetivo: Identificar el riesgo de lesiones por presión en los usuarios de unidades de emergencias médicas.

Método: Estudio descriptivo, transversal y cuantitativo, realizado mediante la aplicación de la escala Braden a 377 pacientes de ocho unidades de Paraná, entre abril y septiembre de 2016. Se emplearon estadísticas descriptivas y el coeficiente de correlación de Spearman, con una significancia de 0,1 para el análisis.

Resultados: Hubo prevalencia de pacientes en riesgo (64,5\%; $n=243)$ y de adultos mayores $(54,6 \% ; n=206)$; los pacientes con alto riesgo de lesiones por presión se encontraban en el departamento de emergencias. La mayoría de las variables se vio conservada, con énfasis en la percepción sensorial $(65,3 \% ; n=246)$. El coeficiente de correlación de Spearman fue de al menos 0,93, e indicó una fuerte correlación entre los resultados obtenidos en las variables y en la escala; se verificó que el riesgo de sufrir lesiones por presión aumenta con la edad.

Conclusiones: La mayoría de los pacientes no estuvo en riesgo; sin embargo, los adultos mayores y las personas tratadas en el departamento de emergencias sí presentaron alto riesgo de desarrollar lesiones por presión.

Palabras clave: Servicios médicos de urgencia. Úlcera por presión. Enfermería de urgencia. Factores de riesgo. Seguridad del paciente. Piel. 


\section{口INTRODUCTION}

Pressure Injury (PI) is defined as localized damage to the skin and/or underlying soft tissue, usually on bone prominence or related to medical devices, resulting from intense and/or prolonged pressure or in combination with shear ${ }^{(1)}$. It is an aggravation considered as an adverse event, a serious worldwide public health problem that mostly affects hospitalized people ${ }^{(2)}$. This condition requires effective actions to minimize the risk, the social and the financial impact of these events ${ }^{(3)}$, including actions in non-hospital emergency services, such as Emergency Care Units (Unidades de Pronto Atendimento, UPAs), which make up, within the scope of Unified Health System in Brazil, the emergency care network and concentrate health care services of intermediate complexity ${ }^{(4)}$.

The complex relation among biomechanical, physiological, and environmental factors predisposes users to a higher risk of developing Pl in emergency departments ${ }^{(3)}$. In Netherlands, for example, a prospective cohort study found a $13 \%$ incidence of $\left.P\right|^{(5)}$, while in Brazil, the prevalence in a university hospital was $40 \%$, and $17.65 \%$ of these injuries were developed in patients admitted to the emergency room ${ }^{(6)}$. In view of the current assistance model, it is known that PI is the third type of adverse event most notified by patient safety centers and stage III PI is the first cause of never events, those that should never happen in health services ${ }^{(7)}$.

Although there are few in studies in Brazilian UPAs, it should also be highlighted that, according to the national report of incidents related to health care, these units constitute the second type of service in the ranking of notification of adverse events, surpassed only by the hospital area, which leads the notifications ${ }^{(7)}$. These data portray the need to join efforts among researchers, managers, and health professionals so that these units can raise better indicators of structure and process, whose objective is to ensure prevention practices with acceptable care results ${ }^{(8-9)}$.

In this sense, there is a consensus on the existence of several risk factors that contribute to the occurrence of $\mathrm{Pl}$ in emergency services, among them, advanced age, impaired mobility, loss of sensitivity, malnutrition, dehydration, and altered level of consciousness ${ }^{(9)}$. These are added to the prolonged waiting time for care or for exams and procedures, generally exceeding the recommended, which is due to the high flow of care associated with the frequent shortage of human resources ${ }^{(10-11)}$. Finally, in these services it is common for patients to wait for care on surfaces that contribute to risk, such as stretchers and wheelchairs, which do not provide the addition of pressure-reducing technologies and care in services that do not have protocols and/or institutional policies for reducing the occurrence of these adverse events to the minimum acceptable $e^{(9)}$.

The early stratification of the risk of developing $\mathrm{Pl}$ in patients admitted to emergency services, by the health professionals, especially nurses, with a view to implementing prevention strategies ${ }^{(9)}$, is relevant in view of the international priorities of patient safety and of the Brazilian policy for the promotion of safe care ${ }^{(12)}$. The quantification of the risk of $\mathrm{PI}$ favors the link between the management of nursing care and the achievement of indicators of excellence in health services, including in UPAs. Therefore, the following is questioned: What is the risk of Pressure Injury in users cared for in Emergency Care Units?

The objective of this research was to identify the risk of Pressure Injury in users of Emergency Care Units.

\section{$\square$ METHOD}

This is a descriptive and cross-sectional study with a quantitative approach, carried out in eight UPAs in Paraná, between April and September 2016. The choice of the participating units was due to their belonging to Curitiba, with direct administration.

The sample calculation was based on the mean number of visits to the emergency, hospitalization, and observation sectors of the eight UPAs between April 2015 and March 2016, which resulted in 21,562 users (8,441 in the emergency,9,645 in the observation, and 3,475 in the hospitalization). In the absence of previous results regarding the application of inspection routes in these locations, a 95\% confidence level, $p=0.5$, and a margin of error of 0.05 were adopted. Thus, the sample size was composed of 377 users stratified by UPA and by service sector (147 for emergency, 169 for observation, and 61 for hospitalization).

The inclusion criterion established was users aged $\geq 18$ years old and who were in care at the time of assessment, in the hospitalization, observation, or emergency sectors. The recruitment of participants took place for convenience, in the morning, afternoon, and night shifts with agreement and signature of the Free and Informed Consent Form. In cases where the user was unable to read and/or understand the form, it was signed by the companion. There were no exclusion criteria.

Data collection was performed by a single nurse with direct observation of the clinical conditions of the users and analysis of the medical records to answer to the items related to the Braden Scale, translated and adapted for Brazil ${ }^{(13)}$. This scale consists of six parameters/subscales, namely: sensory perception, skin moisture, activity, mobility, nutrition, and friction/shear. To each variable, points that varied between 
one (maximum limitation) and four (without limitation) were assigned. At the end, the scores of each subscale were added in order to define the risk value for $\mathrm{Pl}$; scores between 19 and 23 indicated no risk; between 15 to 18 , mild risk; from 13 to 14 , moderate risk; and from 6 to 12, high risk.

These data were recorded together with diverse information related to gender, age, and service sector, then transcribed by double typing for validation and consistency check in a Microsoft Office Excel $2016^{\circ}$ spreadsheet. Descriptive statistics was performed for each item that makes up the Braden scale, as well as Spearman correlation between the items and the scale, using $0.1 \%$ significance. The significance of this test indicates that the correlation coefficient is different from zero, that is, if the indicated value of the correlation can be inferred for the population and not found at random. The software used to develop the analysis was $R$.

This research was extracted from a master's thesis and approved by the Research Ethics Committee of the Health Sciences Sector of the Federal University of Paraná under opinion No.1,376,139, and by the Curitiba City Hall, under No.1,478,366.

\section{RESULTS}

In relation to the participants, $54.6 \%(n=206)$ of the users were in the age group of 60 years old or over and were mostly cared for in the hospitalization sector, as shown in Table 1.

According to the information presented in Table 2, there was a prevalence of users without risk and with similarity between the genders. Regarding the service sectors, there is a difference between the risk of $\mathrm{Pl}$ and the service sector; the majority of the users at high risk (scores $\geq 6$ and $\leq 12$ points) were cared for in the emergency room and those without risk in the observation room.

Most of the parameters/subscales were preserved with emphasis on sensory perception, with $65.3 \%(n=246)$ of the users without limitation. Regarding the items that make up the subscales (activity and mobility), it is highlighted that $32.1 \%(n=121)$ of the users were bedridden and that approximately 20\% ( $n=75)$ were restricted to the chair and/ or had their mobility limited; friction and shearing affected 122 users $(n=32.3 \%)$. Table 3 indicates the prevalence of risk for $\mathrm{Pl}$ among users being cared for in the emergency sector. All the items that make up the subscales (sensory perception, skin moisture, activity, mobility, nutrition, and friction and shear) were shown to be the most limiting factor in this environment, when compared to the hospitalization and observation sectors.

The value of the Spearman correlation coefficient among the variables and scores that make up the Braden scale and the scale itself was at least 0.93, which indicates a strong linear relation among the results. That is, the fact that the user has a score that indicates greater limitation and, consequently, greater risk for $\mathrm{Pl}$, is strongly associated with the others. Thus, the specific analysis for each sub-item was not necessary.

In Figure 1 it can be seen that the risk for PI increases with age in general, but that it does not occur in the same way in all the sectors. For the emergency sector, the increase in risk was linear with increasing age. In the hospitalization sector, it is noted that, after the age of 75 , there is a decrease in the scale value (increased risk for PI), stabilizing until the age of 90 . In the observation sector, the users obtained the maximum value of the scale (lowest risk) regardless of age, with the exception of some over the 75 years old.

Table 1 - Distribution of the users cared for in Emergency Care Units by sector and age group. Curitiba, Paraná, Brazil, 2016

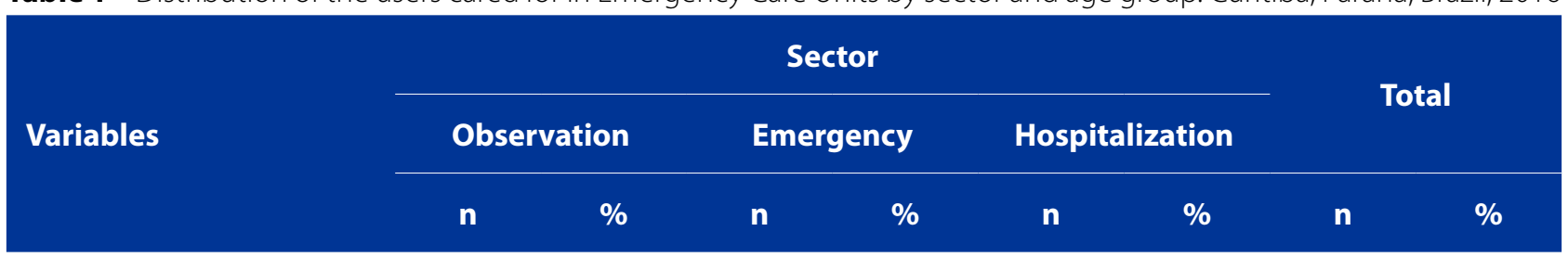

\section{Age group (in years old)}

\begin{tabular}{lccccccccc}
$18-59$ & 116 & 68.6 & 41 & 27.9 & 13 & 21.3 & 171 & 45.4 \\
$\geq 60$ & 53 & 31.4 & 105 & 72.1 & 48 & 78.7 & 206 & 54.6 \\
\hline Total & $\mathbf{1 6 9}$ & $\mathbf{4 4 . 8}$ & $\mathbf{1 4 7}$ & $\mathbf{3 9 . 0}$ & $\mathbf{6 1}$ & $\mathbf{1 6 . 2}$ & $\mathbf{3 7 7}$ & $\mathbf{1 0 0}$ \\
\hline
\end{tabular}

Source: Research data, 2016. 
Table 2 - Distribution of the risk of Pressure Injury among users cared for in Emergency Care Unit according to gender and service sector. Curitiba, Paraná, Brazil, 2016

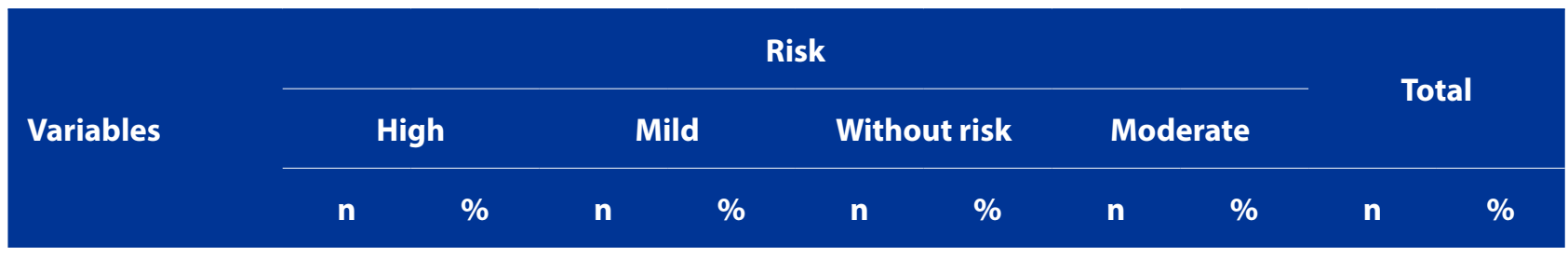

\section{Gender}

$\begin{array}{lllllllllll}\text { Female } & 49 & 22.0 & 14 & 6.3 & 15 & 6.7 & 145 & 65.0 & 223 & 100 \\ \text { Male } & 41 & 26.6 & 05 & 3.3 & 10 & 6.5 & 98 & 63.6 & 154 & 100\end{array}$

\section{Sector}

\begin{tabular}{lcccccccccc} 
Emergency & 72 & 49.0 & 11 & 7.5 & 17 & 11.6 & 47 & 32.0 & 147 & 100 \\
Hospitalization & 17 & 27.9 & 04 & 6.5 & 06 & 9.8 & 34 & 55.7 & 61 & 100 \\
Observation & 01 & 0.6 & 04 & 2.4 & 02 & 1.2 & 162 & 95.8 & 169 & 100 \\
\hline Total & $\mathbf{9 0}$ & $\mathbf{2 3 . 9}$ & $\mathbf{1 9}$ & $\mathbf{5 . 0}$ & $\mathbf{2 5}$ & $\mathbf{6 . 6}$ & $\mathbf{2 4 3}$ & $\mathbf{6 4 . 5}$ & $\mathbf{3 7 7}$ & $\mathbf{1 0 0}$ \\
\hline
\end{tabular}

Source: Research data, 2016.
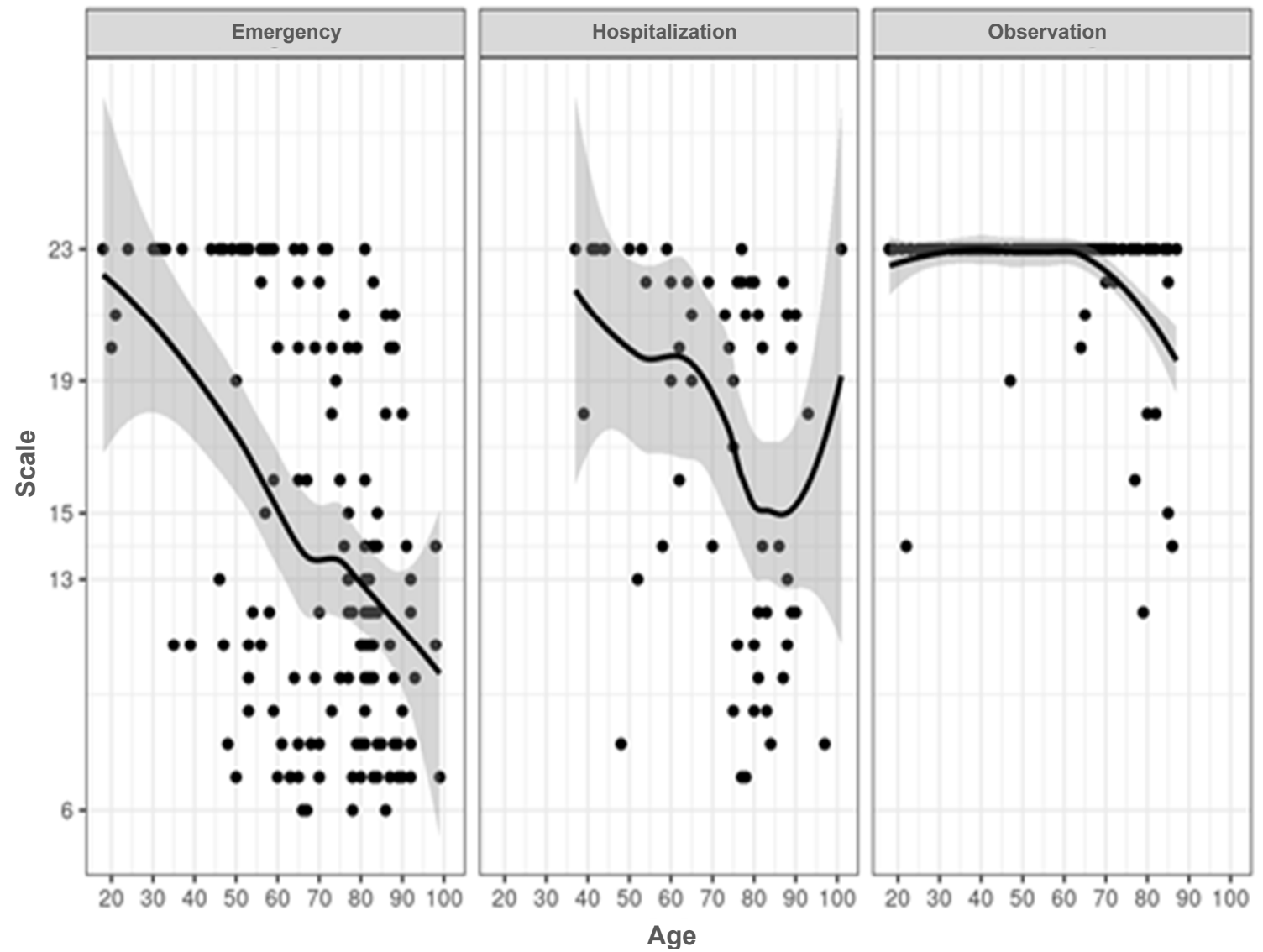

Figure 1 - Distribution of the Braden Scale score related to age and sectors in the Emergency Care Units. Curitiba, Paraná, Brazil, 2016.

Source: Research data, 2016. 
Table 3 - Distribution of the items' scores of the Braden Scale subscales, according to service sector. Curitiba, Paraná, Brazil, 2016

\begin{tabular}{|c|c|c|c|c|c|}
\hline \multirow{3}{*}{ Variables } & \multicolumn{5}{|c|}{ Service sector } \\
\hline & $\begin{array}{c}\text { Emergency } \\
(n=147)\end{array}$ & & & & \\
\hline & $\%$ & $\mathbf{n}$ & $\%$ & n & $\%$ \\
\hline
\end{tabular}

\section{Sensory perception}

Totally limited

Very limited

Slightly limited

No limitation

\section{Skin moisture}

Constantly moist

Very moist

Occasionally moist

Rarely moist

34

27

37

49

Professional

Bedridden

Restricted to the chair

Occasionally walks

Frequently walks

Mobility

Completely immobilized

39

Very limited

Slightly limited

No limitation

\section{Nutrition}

Very poor

Probably inadequate

Adequate

Excellent

Friction and shearing

\begin{tabular}{lcccccc} 
Problem & 55 & 37.4 & 13 & 21.3 & 0 & 0 \\
Potential problem & 39 & 26.5 & 11 & 18.0 & 4 & 2.4 \\
No apparent problem & 53 & 36.1 & 37 & 60.7 & 165 & 97.6 \\
\hline Total & $\mathbf{1 4 7}$ & $\mathbf{1 0 0}$ & $\mathbf{6 1}$ & $\mathbf{1 0 0}$ & $\mathbf{1 6 9}$ & $\mathbf{1 0 0}$
\end{tabular}




\section{DISCUSSION}

In this research, $64.5 \%$ ( $n=243$ ) of the users did not present risk for the development of PI, predominantly those cared for in the observation sector. Among other factors, this can be explained primarily by the profile of users cared for in this sector, composed of young adults with more favorable clinical conditions and less risk when compared to the older adult population. However, it is recognized that these users remain in chairs and armchairs ${ }^{(14)}$, and even on stretchers, awaiting transfer for diagnostic tests or hospital services, conditions favorable to the development of skin lesions which, if not managed, predispose to a risk similar to those in hospital beds in the hospitalization sector ${ }^{(9)}$.

Although the data mainly pointed out users without risk for $\mathrm{Pl}$, it was observed that the risk also increases with increasing age, especially among users cared for in the emergency sector. Lower Braden scale scores were associated with the occurrence of PI in an emergency university hospital (6); therefore, these findings are worrying when observing the profile of users participating in the research, mostly composed of older adults cared for in the hospitalization and emergency sectors.

This result is close to a research study conducted in three UPAs in Rio de Janeiro, Brazil, which pointed out the prevalence of users cared for in the red room aged between 52 and 85 years old $(67.5 \% ; n=231)^{(15)}$, denoting the need to expand the patient safety guidelines, which are still incipient in UPAs, mainly with regard to the management of the risk of $\mathrm{Pl}^{(14)}$. The results also encourage the need to implement institutional protocols that aim to promote good care practices to the population nationwide, including those related to the prevention and early treatment of users at risk or with previous $\mathrm{Pl}^{(12)}$.

It is known that the population aged 60 years old or older presents a higher risk for the development of PI due to changes in the skin and in the subcutaneous tissue related to aging. These, when associated with extrinsic factors, such as prostration for long periods and urinary incontinence, increase this risk ${ }^{(16)}$.

In relation to each item on the Braden scale, the data presented in a study conducted in an Intensive Care Unit for neurotrauma in the Midwest region of Brazil coincide with those found in this study, with a predominance of punctuated items of complete limitation for activity, followed by friction/and shear and immobility ${ }^{(17)}$. Thus, the nurse must consider the subscale scores to implement specific and resolute interventions for the problems encountered ${ }^{(16)}$. In other words, the application of this scale makes it possible to list reliable measures as recommended by the national protocol for the prevention of PI, such as the use of protective barriers to relieve pressure or excessive moisture ${ }^{(12)}$.

It was verified that, among the six parameters of the Braden scale, the item with the lowest score was sensory perception (totally limited/very limited) for users cared for in the hospitalization and emergency sectors. However, when observing that the majority of the users were bedridden or restricted to the chair and with reduced mobility, it is considered relevant to assess the sensory perception at least once per shift. Bearing in mind that reduced mobility is a risk factor for $\mathrm{PI}$ due to the non-reporting of pain as an indicator for decubitus change or repositioning ${ }^{(9)}$, especially among users with reduced level of consciousness, which was associated with a greater number of this problem in emergency sectors ${ }^{(5)}$.

In this research, variables that contribute to the development of PI were not evaluated, for example, associated comorbidities and polypharmacy, use of vasoactive medications, hemodynamic instability, length of stay in the unit, and use of medical devices ${ }^{(6)}$. However, it is considered that mitigating the identified risk factors is relevant to the care provided in UPAs and particularly to the users cared for in the emergency sector, reiterating extrinsic and intrinsic factors associated with them ${ }^{(3)}$.

The prompt identification of users at risk during admission to the emergency service is an important strategy both for prevention ${ }^{(5)}$ and to minimize the exacerbation of $\mathrm{Pl}$, since the decrease in perfusion is cumulative and perpetuated in all the care contexts ${ }^{(9)}$. In addition, the early assessment of injuries already installed allows adopting the most appropriate treatment, and subsidizing the care of nurses in the development of preventive actions with the aim of reducing damage to users, in addition to improving the indicators of processes and results.

In this sense, although it was not the objective of this research, it was noticed that the use of the Braden scale to predict the risk of PI in the investigated context is valid and allows for the immediate adoption of preventive measures beyond the hospital area ${ }^{(12)}$. It is also important to develop studies to assess the sensitivity and specificity of this scale in the context of health care provided in UPAs, considering that screening programs involving the use of risk assessment tools can be useful and targeted at groups of patients at higher risk ${ }^{(18)}$. For example, at the older adult population prevalent in the investigated units, and with the objective to support the multi-professional team in assertive behaviors aimed at care quality. 
Furthermore, stratifying this risk includes the prerogatives of the Brazilian National Patient Safety Program for the adoption of safe practices with a view to reducing the occurrence of adverse events in the health services, by means of leadership, teamwork, and integration of clinical, educational, and managerial aspects ${ }^{(19)}$. These attributes are admittedly essential for the promotion of safe and quality care offered by the health team to users who daily seek the Brazilian UPAs.

\section{a CONCLUSION}

It was verified that more than half of the users evaluated in this research did not present a risk for the development of Pressure Injury; however, routine evaluations are necessary, since a group susceptible to these events was identified, characterized by older adults being cared for in the emergency sector. These results may contribute to the teaching of the theme in undergraduate and graduate courses in order to qualify professionals for the list of strategies aimed at patient safety in Emergency Care Units in Brazil.

The limitations of this research lie in the fact that it did not associate the risk with other variables, such as comorbidities and medication use, which can impact on the risk of Pressure Injury and which may be investigated in subsequent studies.

When considering the Emergency Care Units as a gateway for users of the health system in Brazil, the identification of the risk for Pressure Injury at the admission of the user is configured as necessary in the context of nursing and health, subsidizing the planning of preventive and realistic actions to each user.

\section{REFERENCES}

1. National Pressure Injury Advisory Panel [Internet]. Westford, MA: c2016-2020 [cited 2019 Jun 27]. NPIAP Pressure Injury Stages; [about 1 screen]. Available from: https://cdn.ymaws.com/npuap.site-ym.com/resource/resmgr/npuap_ pressure_injury_stages.pdf

2. Tonole R, Silva Brandão E. Human resources and materials for the prevention of pressure ulcers. Rev Enferm UFPE on line. 2019;12(8):2170-80. doi: https://doi. org/10.12957/reuerj.2019.38472

3. Santamaria N, Creehan S, Fletcher J, Alves P, Gefen A. Preventing pressure injuries in the emergency department: Current evidence and practice considerations. Int Wound J. 2019:16(3):746-52. doi: https://doi. org/10.1111/iwj.13092

4. Ministério da Saúde (BR). Portaria № 10, de 03 de janeiro de 2017: redefine as diretrizes de modelo assistencial e financiamento de UPA 24h de Pronto Atendimento como componente da Rede de Atenção às Urgências, no âmbito do Sistema Único de Saúde. Diário Oficial da União [da] República Federativa do Brasil, Brasília, DF, 2017 jan 04; 154(3 Seção 1):34-7.
5. Ham HW, Schoonhoven L, Schuurmans MJ, Leenen LPH. Pressure ulcer development in trauma patients with suspected spinal injury: the influence of risk factors present in the Emergency Department. Int Emerg Nurs. 2017;30:139. doi: https://doi.org/10.1016/j.ienj.2016.05.005

6. Bernardes RM, Caliri MHL. Prevalência de úlcera por pressão em um hospital de emergência: estudo transversal. Online Braz J Nurs. 2016;15(2). doi: https://doi. org/10.17665/1676-4285.20165391

7. Agência Nacional de Vigilância Sanitária (BR), Gerência de Vigilância e Monitoramento em Serviços de Saúde, Gerência Geral de Tecnologia em Serviços de Saúde. Boletim Segurança do Paciente e Qualidade em Serviços de Saúde no 15: incidentes relacionados à assistência à saúde 2016. Brasília: ANVISA; 2017 [cited 2019 Jun 28]. Available from: http:// portal.anvisa.gov.br/documents/33852/271855/Boletim+Segurança +do+Paciente+e+Qualidade+em+Serviços+de+Saúde+nº+15/ bb637392-4973-4e7f-8907-a7b3af1e297b

8. Kottner J, Hahnel E, Lichterfeld-Kottner A, Blume-Peytavi U, Büscher A. Measuring the quality of pressure ulcer prevention: a systematic mapping review of quality indicators. Int Wound J. 2018;15(2):218-24. doi: https://doi. org/10.1111/iwj.12854

9. Spader C. Collaboration improves pressure injury prevention. Am Nurse Today. 2018 [cited 2019 Jun 26];13(5 suppl):29-30. Available from: https://www. americannursetoday.com/wp-content/uploads/2018/05/DabirSupplement_ May2018.pdf

10. Silva ADC, Chianca TCM, Pádua DR, Guimarães $G$ de L, Manzo BF, Correa AR. Characteristics of care of a public emergency room according to the Manchester Triage System. Rev Min Enferm. 2019;23:e-1178. doi: https://doi. org/10.5935/1415-2762.20190026

11. Machado CV, Lima LD, O'Dwyer G, Andrade CLT, Baptista TWF, Pitthan RGV, et al. [Workforce management in Emergency Care Units: government strategies and profile of healthcare professionals]. Cad Saúde Pública. 2016;32(2):e00170614. Portuguese. doi: https://doi.org/10.1590/0102-311X00170614

12. Ministério da Saúde (BR) [Internet]. Brasilia (DF): Ministério da Saúde; c2013-2020 [cited 2019 Aug 06]. Protocolos básicos de segurança do paciente; [aprox. 1 tela]. Available from: http:// portalsaude.saude.gov.br/index.php/index.php?option=com_ content\&view $=$ article\&id $=28202 \&$ catid $=1243 \& \mid$ temid $=187$

13. Paranhos WY, Santos VLCG. Avaliação de risco para úlceras de pressão por meio da escala de Braden, na língua portuguesa. Rev Esc Enferm USP. 1999 [cited 2019 Jun 23];33(nesp):191-206. Available from: http://www.ee.usp.br/ reeusp/upload/pdF/799.pdF

14. Paixão DPSS, Batista J, Maziero ECS, Alpendre FT, Amaya MR, Cruz EDA. Adhesion to patient safety protocols in emergency care units. Rev Bras Enferm. 2018;71(Suppl 1):577-84. doi: https://doi. org/10.1590/0034-7167-2017-0504

15. Soares TCS, Mata CB, Silva RCL, Peregrino AAF, Santiago LC, Schutz V. Profile of users served in the red room of a 24 hour health unit. J Nurs UFPE on line. 2016 [cited 2019 Aug 11];10(12):4619-27. Available from: https://periodicos.ufpe.br/revistas/revistaenfermagem/article/view/11531

16. Machado LCLR, Fontes FLL, Sousa JERB, Sousa Neta AS, Alencar EJC, Costa $A C R R$, et al. Fatores de risco e prevenção de lesão por pressão: aplicabilidade da Escala de Braden. Rev Eletron Acervo Saúde. 2019;(21 supl):e635. doi: https://doi.org/10.25248/reas.e635.2019 
17. Santos $L R C L$, Lino AlA. Riscos de lesão por pressão: aplicação da Escala de Braden em terapia intensiva. ESTIMA Braz J Enterostomal Ther. 2018;16:e0818. doi: https://doi.org/10.30886/estima.v16.443_PT

18. Børsting TE, Tvedt CR, Skogestad IJ, Granheim TI, Gay CL, Lerdal A. Prevalence of pressure ulcer and associated risk factors in middle- and older-aged medical inpatients in Norway. J Clin Nurs. 2018;27(3-4):e535-43. doi: https://doi. org/10.1111/jocn. 14088

\section{- Corresponding author:}

Danieli Parreira da Silva

E-mail: d_enf@yahoo.com.br
19. Agência Nacional de Vigilância Sanitária (BR). Nota técnica GVIMS/GGTES № 03 - Práticas seguras para prevenção de Lesão por Pressão em serviços de saúde. Brasília: ANVISA, 2017 [cited 2019 Aug 11]. Available from: http:// portal.anvisa.gov.br/documents/33852/271855/Nota+Técnica+GVIMSGGTES+nº+03-2017/54ec39f6-84e0-4cdb-a241-31491ac6e03e

\section{Associate editor:}

Dagmar Elaine Kaiser

Editor-in-chief:

Approved: 04.28.2020
Maria da Graça Oliveira Crossetti 